液体水素-超電導ハイブリッドエネルギー輸送システムの検討

中山 知紀 ${ }^{* 1, * 2, \dagger}$, 大友 勝志 ${ }^{* 1}$, 谷貝 剛 ${ }^{* 1}$, 津田 理 ${ }^{* 1}$, 濱島 高太郎 ${ }^{* 1}$

\title{
Survey of Hybrid Energy Transportation System Combined with Liquid Hydrogen Pipeline and Superconducting Cable
}

\begin{abstract}
Tomonori NAKAYAMA ${ }^{* 1,{ }^{*}, \dagger}$, Katsushi OTOMO*1 ${ }^{*}$ Tsuyoshi YAGAI ${ }^{* 1}$, Makoto TSUDA ${ }^{* 1}$ and Takataro HAMAJIMA ${ }^{* 1}$
Synopsis: It is expected that liquid hydrogen $\left(\mathrm{LH}_{2}\right)$ will be utilized for energy transportation and storage. The $\mathrm{LH}_{2}$ maintained in storage tanks is capable of generating electric power for a long time through fuel cells (FCs) without emission of carbon dioxide $\left(\mathrm{CO}_{2}\right)$, and can cool high-temperature superconducting (HTS) machines, such as SMES and HTS cable, as well. We propose a hybrid energy transportation system composed of $\mathrm{LH}_{2}$ transfer pipeline, a FC system and HTS cable. We studied the power efficiency of the hybrid system and the pipeline design. We estimated the loss in the $\mathrm{LH}_{2}$ transfer pipeline with HTS cable and optimized the pipeline design. It was found that the hybrid energy transportation system has lower loss than conventional electric power cable. Since this system can transport not only $\mathrm{LH}_{2}$, but also large electric power with small loss, twice the amount of electric power can be supplied when large power load is required at peak times. .
\end{abstract}

Keywords: liquid hydrogen, energy transportation system, superconducting cable, transfer loss

\section{1. はじめに}

地球温暖化など地球環境問題から，環境負荷が小さな燃 料として水素が期待されている。水素は，燃料電池の燃料 として使用するとき廃棄物として水のみを排出し, 二酸化 炭素を放出しない。また，発生した水は純粋なものであり， これはただちに水素製造の原料になる。水素はこのように 枯渇の心配がなく持続可能なエネルギー源といえる。しか し，水素の持つエネルギーは 2 次エネルギーであり， 1 次 エネルギー源を用い, 水の電気分解や熱分解, 光触媒によ る分解などの方法で水素を製造しなければならない。地球 環境に対する水素利用の要望から, 水素の製造は, 環境污 染がなく発電できる風力や太陽光などの再生可能エネル ギーによって行われなければならない。

水素の運輸や貯蔵において, 密度の観点から液体状態で 保存するのが望ましい ${ }^{1-2)}$ 。液体水素の体積密度は 1 気圧 下で $70.8 \mathrm{~kg} / \mathrm{m}^{3}$ であり, 圧縮ガス水素の $25 \sim 40 \mathrm{~kg} / \mathrm{m}^{3}$ や水

\footnotetext{
Received July 7, 2008

${ }^{*} 1$ 東北大学大学院工学研究科

干980-8579 宮城県仙台市青葉区荒巻字青葉 6-6-05

School of Engineering, Tohoku University, 6-6-05, Aaramakiaza

Aoba, Aoba-ku, Sendai, Miyagi 980-8579, Japan

*2 (独) 日本学術振興会

干102-8472 東京都千代田区一番町 8 番地

Japan Society for the Promotion of Science, 8 Ichibancho,

Chiyoda-ku, Tokyo 102-8472, Japan

† E-mail: tmnr-n@ecei.tohoku.ac.jp
}

素吸蔵合金の 40 65 kg/m³ に比べて省スペースで貯蔵可能 である。また, 液体水素は質量密度が最も高いので, 車載 用燃料としても有望である。しかし, 液体水素は 1 気圧下 での沸点が $20.3 \mathrm{~K}$ である極低温液体であるため, 液体状 態を維持するには熱侵入による蒸発や冷凍機動力を含めた 損失を考慮する必要がある。

一方, 地球環境問題解決への別のアプローチとして, 省 エネルギーがある。超電導機器は, 高効率に電力を発生, 利用でき, 低損失で電力を輸送, 貯蔵できるため, 省エネ ルギー対策技術として非常に重要な技術である。超電導体 の中でも, 2000 年に発見され, 盛んに研究開発が進めら れている $\mathrm{MgB}_{2}$ 超電導体 ${ }^{3)}$ の泠媒として液体水素が注目 されている。また, $\mathrm{Bi}$ 系, $\mathrm{Y}$ 系などの高温超電導体を液 体水素で冷却すると, 液体窒素を冷媒として用いた場合に 比べ臨界電流密度を 1 椼近く高くすることができる ${ }^{4-6)}$ 。 液体水素と超電導の組み合わせを考えると, 水素は輸送, 貯蔵の観点から液化動力が必要であるが, 液化された水素 の冷熱を SMES やケーブルなどの超電導機器に適用し, 共通化することで全体の損失を低減し, 相乗効果を期待で きる ${ }^{7-12)}$ 。

本研究では, 省エネルギーが期待される液体水素と超 電導によってエネルギーを輸送する, 液体水素-超電導八 イブリッドエネルギー輸送システムを提案する。将来にお いて有望とされる水素が社会のさまざまな分野で利用され るようになるとすると, その輸送方法を検討しておくこと 
は重要である。ここでエネルギーの輸送方法では，石油や ウラン, 水素などのエネルギー源を輸入・貯蔵している地 点で電力に変換し, 送電線によって電気エネルギーとして 輸送する方法が，一般的に効率が高いと考えられている。 液体水素をパイプラインによって輸送するとき，従来の送 電線による電力輸送に比べて省エネルギーを実現できるか を検討・比較し，実現可能ならば液体水素パイプラインに 超電導ケーブルを設置して同時に電力エネルギーを輸送で きるハイブリッドエネルギー輸送システムは有望なシステ ムとなる。

\section{2. 液体水素の特性}

高温超電導機器の冷媒として, 液体へリウム, 液体水素, 液体窒素がある。液体へリウムは高価かつ資源が少ないた め, ケーブルのような多量の流体を必要とするシステムに は適さない。Table 1 に液体水素と液体窒素の熱的および 輸送性に関係する物性值を示す。Table 1 から, 液体水素 の粘性係数は液体窒素に比べて $1 / 10$ 程度であるため, 同 じ圧力損失でより遠くまで液体水素を送ることができる。 今回検討するハイブリッドエネルギー輸送パイプラインで は，液体水素への熱侵入や輻射を低減するために，熱シー ルドに液体窒素を用いる。

\section{3. 液体水素-超電導複合エネルギー輸送システム}

\section{1 エネルギ一輸送}

一般的に使用されるエネルギー形態のうち，電気エネル ギーは最も付加価值が高く, 需要家にとっても利用しやす い形態である。需要地まで電力ケーブルによって送電する 方法は，他のエネルギー輸送方法よりも効率が良いとされ ている。日本において 275 kV-500 MVA 級送電線での損失 は $2 \%$ 前後であり，本研究では 500MVA CV ケーブルの単 位長さ当たりの損失を $127 \mathrm{~W} / \mathrm{m}$ とした ${ }^{13)}$ 。

Fig. 1 に検討を行ったエネルギー輸送方法の 2 つを示 す。Fig. 1(a)は，従来の送電線による電力輸送であり， Fig. 1(b)は, 今回提案した超電導-液体水素複合エネルギー 輸送システムである。超電導と液体水素のハイブリッドシ ステムは, 液体水素パイプラインによって化学エネルギー を輸送し，パイプライン中に敷設した超電導ケーブルに よって電気エネルギーを伝送する。最終的なエネルギー需 要が電気エネルギーであるとして, 液体水素をパイプライ ンで需要地まで輸送し, 需要地にて燃料電池によって電力 に変換してエネルギーを供給するシステムとした。従来 ケーブルと比較して, 超電導ケーブルは総合損失を低下で きることが分かっている。14-15)。本検討では, Fig. 1 に示 す Point S-Point R 間の損失を計算し，液体水素エネルギー 輸送と従来ケーブルによるエネルギー輸送を比較する。

\section{2 液体水素輸送パイプライン}

Fig.2 に液体水素-超電導複合エネルギー輸送パイプライ
Table 1 Properties of liquid hydrogen $\left(\mathrm{LH}_{2}\right)$ and liquid nitrogen $\left(\mathrm{LN}_{2}\right)$ as the refrigerant of a superconducting cable.

\begin{tabular}{c|c|c}
\hline item & $\mathrm{LH}_{2}$ & $\mathrm{LN}_{2}$ \\
\hline \hline Boiling point $T[\mathrm{~K}]$ & 20.3 & 77.3 \\
\hline $\begin{array}{c}\text { Volumetric density } \rho \\
{\left[\mathrm{kg} / \mathrm{m}^{3}\right]}\end{array}$ & 70.8 & 808.6 \\
\hline Viscosity $\mu[\mu \mathrm{Pa} \cdot \mathrm{s}]$ & 12.5 & 142.9 \\
\hline Latent heat $[\mathrm{kJ} / \mathrm{kg}]$ & 443.0 & 195.6 \\
{$\left[\mathrm{MJ} / \mathrm{m}^{3}\right]$} & 31.4 & 158.2 \\
\hline Specific heat $[\mathrm{kJ} / \mathrm{kg} \cdot \mathrm{K}]$ & 11.0 & 1.1 \\
{$\left[\mathrm{~kJ} / \mathrm{m}^{3} \cdot \mathrm{K}\right]$} & 778.8 & 889.5 \\
\hline Heating value $Q_{\mathrm{LH} 2}[\mathrm{MJ} / \mathrm{kg}]$ & 120.1 & - \\
\hline \multicolumn{2}{|c}{}
\end{tabular}

(a)

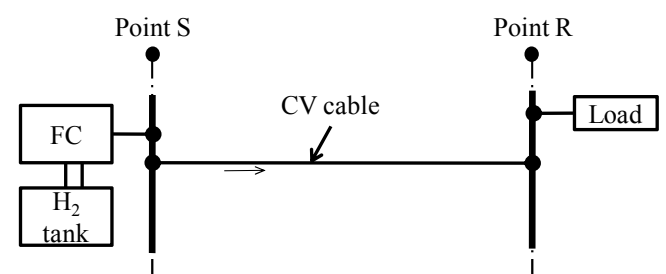

(b)

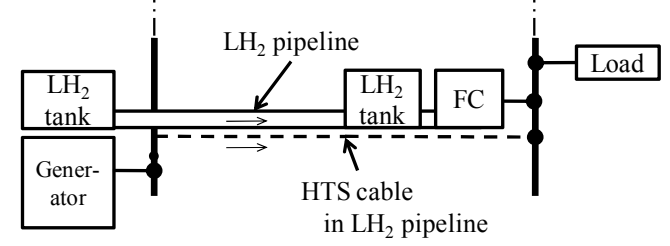

Fig. 1 Schematic of a conventional power transfer cable and $\mathrm{LH}_{2}$ transfer pipeline with HTS cable.

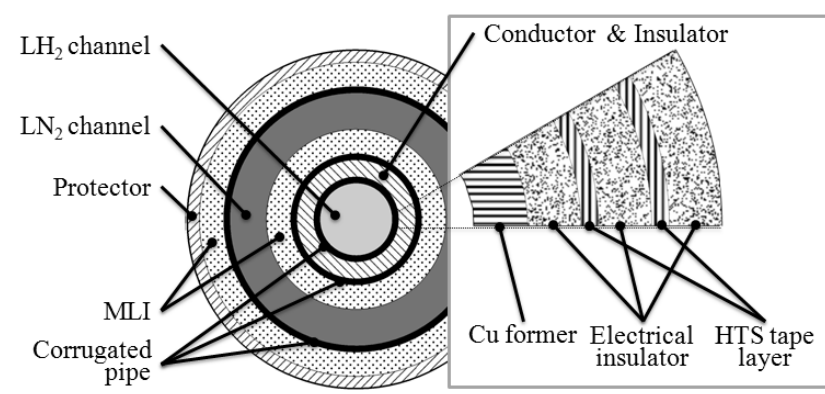

Fig. 2 Cross-section of a $\mathrm{LH}_{2}$ transfer pipeline with HTS electric power cable.

ンの断面図を示す。パイプラインは外側から順に, 保護 層, 真空多層断熱層(MLI: Multi-Layer Insulator), ステンレ スコルゲート管(SUS 管), 液体窒素流路, MLI, SUS 管, 導体層[電気絶縁紙-HTS(-)-絶縁紙-HTS(+)-絶縁紙-フォー マ], 液体水素流路となっている。導体は直流バイポール 送電とし, $\mathrm{DC} \pm 25 \mathrm{kV}$ を想定した。このとき必要な絶縁厚 さは OPPL(Oriented polypropylene laminated)を用いて 1.3 $\mathrm{mm}$ 程度である。本検討ではインパルス強度も考慮して絶 縁厚さを $3 \mathrm{~mm}$ とした。Table 2 に設計条件を示す。冷凍 機設置間隔は $5 \mathrm{~km}$ とし，この間の圧力損失と冷媒の温度 上昇が規定值に収まるように設計する。Table 3 に解析に 
用いた各種材質特性值と各補器類の効率を示す 16-18)。パ イプライン設計において, 圧力損失は $0.1 \mathrm{MPa}$, 温度上昇 は $0.6 \mathrm{~K}$ 程度であるので, 各物性值に大きな変化はないも のとし，輸送開始地点での物性值を使用した。

Fig. 1 の Point-R で, 従来ケーブルで伝送した電力 $P$ と 同等の電力を燃料電池から得るための液体水素の流量 $\dot{m}$ は，式(1)となる。

$$
\dot{m}=\frac{P}{\eta_{\mathrm{FC}} Q_{\mathrm{LH}_{2}}} \quad[\mathrm{~kg} / \mathrm{s}]
$$

$\eta_{\mathrm{FC}}$ ：燃料電池の発電効率

$Q_{\mathrm{LH} 2}$ : 水素の燃燒熱量 $[\mathrm{MJ} / \mathrm{kg}]$

円管内を流体が平均流速 $v[\mathrm{~m} / \mathrm{s}]$ で管路長 $l[\mathrm{~m}]$ だけ流れる ときの損失へッド $h$ は式(2)で表される。

$$
\begin{aligned}
& h=\lambda \frac{l}{d} \frac{v^{2}}{2 g} \quad[\mathrm{~m}] \\
& \lambda: \text { 摩擦損失係数 } \\
& v: \text { 流速 } v=\dot{m} /(\rho \cdot S)[\mathrm{m} / \mathrm{s}] \\
& d: \text { 等価管直径 }[\mathrm{m}] \\
& g: \text { 重力加速度 }\left[\mathrm{m} / \mathrm{s}^{2}\right] \\
& S: \text { 等価管路断面積 }\left[\mathrm{m}^{2}\right] \\
& \rho: \text { 流体の密度 }\left[\mathrm{kg} / \mathrm{m}^{3}\right]
\end{aligned}
$$

ここで，入は式(3)で表される。

$$
\begin{array}{ll}
\lambda=\frac{64}{R e} & (\operatorname{Re} \leq 2320) \\
\lambda=\frac{0.3164}{R e^{0.25}} & \left(2320<R e \leq 10^{5}\right) \\
\lambda=0.0032+\frac{0.0221}{R e^{0.237}} & \left(10^{5}<R e \leq 3 \times 10^{6}\right) \\
R e: \text { レイノルズ数 } R e=\rho v d / \mu & R: \text { 流体の粘性係数 }[\mathrm{Pa} \cdot \mathrm{s}]
\end{array}
$$

また, 圧力損失に伴う管摩擦損失 $P_{\mathrm{f}}$ は式(4)で表される。

$$
P_{\mathrm{f}}=\dot{m} g h \quad[\mathrm{~W}]
$$

液体水素と液体窒素のそれぞれの場合について，式(4)よ り管摩擦損失を求めた。

次にパイプラインへの熱侵入を考える。パイプラインヘ の熱侵入 $P_{\mathrm{h}}$ は式(5)で表される。

$$
P_{\mathrm{h}}=\frac{2 \pi l}{\sum_{j=1}^{n} \frac{1}{k_{j}} \ln \frac{d_{j+1}}{d_{j}}}\left(T_{\text {out }}-T_{\text {ref }}\right)
$$

\begin{tabular}{|c|c|c|c|}
\hline & $\begin{array}{c}\text { Radial build } \\
\text { [mm] }\end{array}$ & Other condition \\
\hline \multicolumn{2}{|r|}{$\begin{array}{c}\text { Radius of } \\
\mathrm{LH}_{2} \text { channel }\end{array}$} & $100 \sim 400$ & $\begin{array}{c}\Delta T_{\mathrm{LH} 2}<1 \mathrm{~K} \\
v_{\mathrm{LH} 2}<10 \mathrm{~m} / \mathrm{s} \\
\Delta P_{\mathrm{LH} 2}<0.1 \mathrm{MPa}\end{array}$ \\
\hline \multirow{9}{*}{ 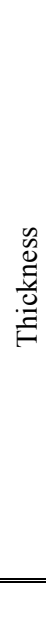 } & $\begin{array}{c}\text { Conductor layer } \\
\text { (Former) } \\
\text { (Electrical insulator) } \\
\text { (HTS tape layer) }\end{array}$ & $\begin{array}{c}14 \\
(3) \\
(3 \times 3 \text { layer }) \\
(1 \times 2 \text { layer }) \\
\end{array}$ & $\begin{array}{l}\text { DC } 50 \mathrm{kV}( \pm 25 \mathrm{kV}) \\
\text { DC } 0.4 \mathrm{kA} \sim 40 \mathrm{kA} \\
\text { Cu sheathed } \mathrm{MgB}_{2} \\
\text { Stabilizer ratio } 5.0\end{array}$ \\
\hline & Corrugated pipe & 5 & \\
\hline & Inner MLI & $10 \sim 30$ & \\
\hline & Corrugated pipe & 5 & \\
\hline & $\mathrm{LN}_{2}$ channel & $10 \sim 50$ & $\begin{array}{c}\Delta T_{\mathrm{LN} 2}<5 \mathrm{~K} \\
v_{\mathrm{LN} 2}<10 \mathrm{~m} / \mathrm{s} \\
\Delta P_{\mathrm{LN} 2}<0.1 \mathrm{MPa}\end{array}$ \\
\hline & Corrugated pipe & 5 & \\
\hline & Outer MLI & $5 \sim 30$ & \\
\hline & Protector & 10 & \\
\hline & Outer radius & $154 \sim 549$ & \\
\hline
\end{tabular}

\begin{tabular}{|c|c|c|c|}
\hline Pipeline material & $\begin{array}{c}\text { Equivalent } \\
\text { thermal } \\
\text { conductivity } \\
k[\mathrm{~W} / \mathrm{m} \cdot \mathrm{K}]\end{array}$ & Machine & $\begin{array}{c}\text { Efficiency } \\
\eta\end{array}$ \\
\hline PVC pipe @300 K & 0.15 & Fuel cell & 0.4 \\
\hline $\begin{array}{c}\text { SUS corrugated pipe } \\
\text { @77 K } \\
@ 20 \mathrm{~K}\end{array}$ & $\begin{array}{l}7.335 \\
2.014\end{array}$ & \begin{tabular}{|c}
$\mathrm{LH}_{2}$ \\
refrigerator \\
system \\
\end{tabular} & 0.02 \\
\hline $\begin{array}{c}\text { MLI }^{17-18)} \\
\text { Outer @ } 977 \mathrm{~K} \\
\text { Inner @20 K }\end{array}$ & $\begin{array}{l}5.0 \times 10^{-5} \\
7.0 \times 10^{-5}\end{array}$ & \begin{tabular}{|c|}
$\mathrm{LN}_{2}$ \\
refrigerator \\
system \\
\end{tabular} & 0.1 \\
\hline HTS tape @20 K & 1000 & & \\
\hline PP insulator @20 K & 0.1 & & \\
\hline $\mathrm{Cu}$ former@20 K & 1366 & & \\
\hline
\end{tabular}

$T_{\text {out }}$ : 外気温 $300 \mathrm{~K}$ or $77 \mathrm{~K}$

$T_{\text {ref: }}$ 冷媒温度 $77 \mathrm{~K}$ or $20 \mathrm{~K}$

$k_{\mathrm{j}}$; パイプライン各層の等価熱伝導率 $[\mathrm{W} / \mathrm{m} \cdot \mathrm{K}]$ 液体窒素への熱侵入は，300 77 K 間で，保護層，MLI， SUS 管の合計 3 層を考え, Table 3 に示す等価熱伝率およ び管直径を用いて式(5)によって計算した。液体水素への 熱侵入も 77 20 K 間で，MLI，SUS 管，導体層，SUS 管の 合計 9 層を考え Table 3 の等価熱伝導率および管直径を用 いて解析を行った。
Table 2 Design conditions for a $\mathrm{LH}_{2}$ transfer pipeline using a with HTS electric power cable.

The refrigerator interval is $5 \mathrm{~km}$.

Table 3 Properties of each pipeline material and machine.

液体水素温度の冷凍機効率 $\eta_{\mathrm{LH} 2}$ を 0.02 , 液体窒素温度の 冷凍機効率 $\eta_{\mathrm{LN} 2}$ を 0.1 として, 冷凍機動力まで含めた全 損失 $P_{\text {total }}$ は式(6)で表される。

$$
P_{\text {total }}=\frac{1}{\eta_{\mathrm{LH} 2}}\left(P_{\mathrm{fLH} 2}+P_{\mathrm{hLH} 2}\right)+\frac{1}{\eta_{\mathrm{LN} 2}}\left(P_{\mathrm{fLN} 2}+P_{\mathrm{hLN} 2}\right)[\mathrm{W}]
$$

\section{3 損失の比較}

輸送エネルギーが $500 \mathrm{MW}$ の場合の損失は, 液体水素 流路半径, 液体窒素流路外半径, 各 MLI 層厚みを变数と して計算した。従来の $275 \mathrm{kV}$ 級 $500 \mathrm{MVA} \mathrm{CV}$ ケーブルの 損失 $127 \mathrm{~W} / \mathrm{m}$ の 1/4(32 W/m)を目標としてパイプラインを 設計した。Fig. 3 の縦軸に内側 MLI 半径方向厚さおよび横 
Table 4 An example of radial builds of each $\mathrm{LH}_{2}$ pipeline design.

\begin{tabular}{c|l|l|l|l|l|c}
\hline & $\begin{array}{l}\text { Total } \\
\text { loss }\end{array}$ & $\begin{array}{l}\mathrm{LH}_{2} \\
\text { channel }\end{array}$ & $\begin{array}{l}\text { Inner MLI } \\
\text { thickness }\end{array}$ & $\begin{array}{l}\mathrm{LN}_{2} \\
\text { channel }\end{array}$ & $\begin{array}{l}\text { Outer MLI } \\
\text { thickness }\end{array}$ & $\begin{array}{l}\text { Outer } \\
\text { radius }\end{array}$ \\
\hline \hline $500 \mathrm{MW}$ & $30.8 \mathrm{~W} / \mathrm{m}$ & $180 \mathrm{~mm}$ & $25 \mathrm{~mm}$ & $20 \mathrm{~mm}$ & $26 \mathrm{~mm}$ & 290 \\
\hline $1 \mathrm{GW}$ & $30.8 \mathrm{~W} / \mathrm{m}$ & $300 \mathrm{~mm}$ & $40 \mathrm{~mm}$ & $20 \mathrm{~mm}$ & $32 \mathrm{~mm}$ & 431 \\
\hline
\end{tabular}

軸に液体水素流路半径をとったときの液体水素に発生する 損失が一定となるラインを示す。Fig. 3 より，MLI 半径方 向厚さが一定のとき, 液体水素流路半径を増加させると 175 250 mm のあたりで損失が極小值をとる。これは，流 路径が大きくなり摩擦損失が減る一方, 径の増加に伴って 熱侵入が増加するためである。Fig. 3 より損失が小さくか つ, MLI 厚さが小さくなる点を選択してパイプライン設 計を行った。液体窒素も同様に, 外側 MLI 半径方向厚さ および液体窒素流路半径から適切な值を選択しパイプライ ン設計を行った。 $5 \mathrm{~km}$ ごとに設置する冷凍機ステーショ ンの動力を一定としたとき, 容量 $1 \mathrm{GW}$ の液体水素パイプ ラインの設計も行った。今回の検討において，使用する MLI 量とパイプライン最外半径が最も小さくなるパイプ ライン構成を Table 4 に示す。

Fig. 4 に，Table 4 の $500 \mathrm{MW}$ 輸送用パイプラインに定格 值以外の液体水素を輸送した時の様子を示す。Fig. 4 の実 線は液体水素の温度変化を, 破線は圧力損失を表してい る。500 MW 用パイプラインは, 輸送エネルギーが $1 \mathrm{GW}$ までのとき, 液体水素の圧力損失および温度上昇は規定值 の中にあり, 液体水素を安定して輸送できる。また, 1 $\mathrm{GW}$ エネルギー輸送時，損失は $80 \mathrm{~W} / \mathrm{m}$ となり， Table 4 に 示した $1 \mathrm{GW}$ 輸送最適構成の 2 倍以上となる。このこと は, 液体水素パイプラインは輸送エネルギーの設計值近傍 で利用することが望ましいが，液体水素の需給バランスが 釣り合わなくなった場合でも適応できることを意味してい る。

\section{4 超電導ケーブル}

輸送距離が $5 \mathrm{~km}$ 程度の液体水素の輸送は直接の電力輸 送より省エネルギーとなることが分かった。前述したよう に, 液体水素の泠熱を用いると超電導ケーブルで電力も極 めて少ない損失で輸送できるので, 液体水素パイプライン 中に超電導ケーブルを設置した構成を考え, その検討を行 う。

本論文では，超電導テープ線材は，幅 $3.6 \mathrm{~mm} \times 0.65 \mathrm{~mm}$ の $\mathrm{MgB}_{2}$ テープ線材を用いて検討を行った ${ }^{19)}$ 。超電導ケー ブルの巻き付け半径は液体水素流路半径によって変化し, 例えば, Table 4 の $500 \mathrm{MW}$ のエネルギー輸送時では, 約 $191 \mathrm{~mm}$ である。この巻き付け半径において, $\mathrm{MgB}_{2}$ 超電 導テープは 1 層約 300 本配置できる。テープ 1 枚の臨界 電流は自己磁場約 $0.1 \mathrm{~T}$ の条件下で, $300 \mathrm{~A}$ となるので, ケーブルの臨界電流は $90 \mathrm{kA}$ となる。したがって, 直流電 圧を $\pm 25 \mathrm{kV}$ (対地電圧 $50 \mathrm{kV}$ ), 負荷率 $60 \%$ とすると $2.7 \mathrm{GW}$

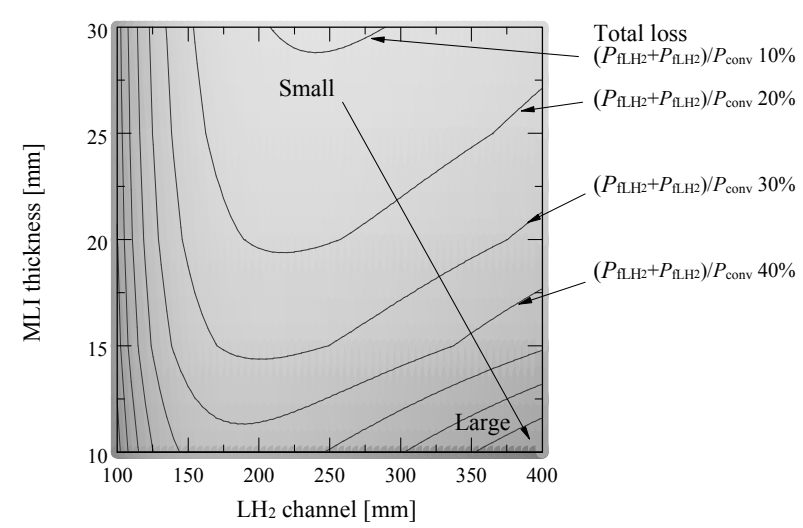

Fig. 3 Dependence of total $\mathrm{LH}_{2}$ transfer loss $P_{\text {total }}$ on the $\mathrm{LH}_{2}$ channel and Multi-Layer Insulator (MLI) thickness.

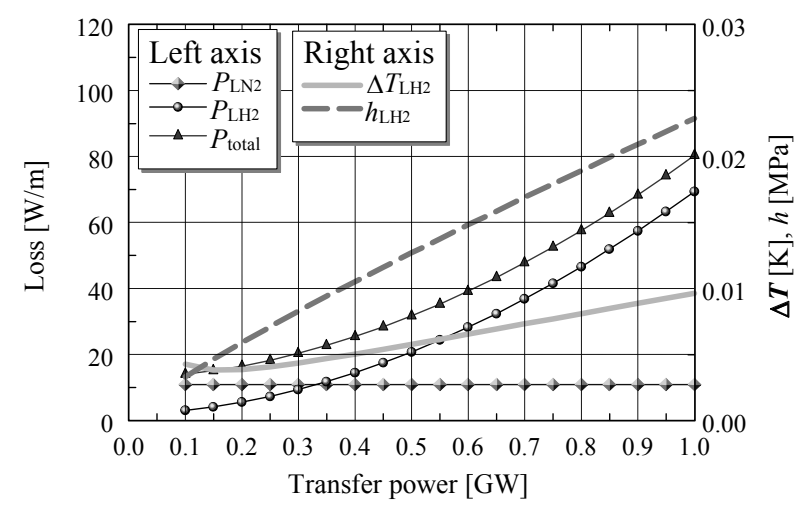

Fig. 4 Characteristics of transmission power vs. losses in a $500 \mathrm{MW} \mathrm{LH}_{2}$ pipeline.

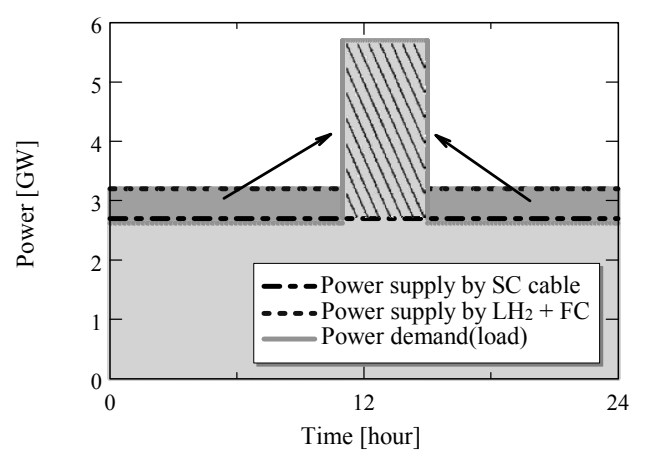

Fig. 5 Schematic of electric power load leveling using stored $\mathrm{LH}_{2}$ and $\mathrm{FC}$.

の電力を送電できる。液体水素-超電導ハイブリッドエネ ルギー輸送システムは, 通常の電力 $2.7 \mathrm{GW}$ と液体水素に よる貯蔵性の電力換算エネルギーを $500 \mathrm{MW}$ 輸送でき る。このことは, Fig. 5 に示すような昼間に電力が不足す 
る電力需給状態のとき, 貯蔵していた水素により負荷平準 化を行える可能性を示している。例えば， 1 日のうちの 4 時間水素を使用して発電すると仮定すると, ピーク電力を $5.7 \mathrm{GW}$ まで増加できる。

超電導ケーブルが直流で運転される場合，送電損失は 極めて少なく，熱侵入や摩擦損失も液体水素パイプライン の損失として計算すると, 超電導ケーブルのトータルの損 失を無視することができる。このように, 液体水素と超電 導の複合化は, 超電導にとっても大きなメリットである。

\section{4. まとめ}

液体水素と超電導の複合エネルギー輸送システムの設 計を行って総合損失を求めた。今回提案したハイブリッド エネルギー輸送システムは, 従来の CV ケーブルよりも損 失を低減できる可能性を示した。

液体水素中の超電導ケーブルは, 液体窒素で冷却された 高温超電導ケーブルよりも臨界電流が 5 10 倍程度大きく なるので，送電においても大きな利点がある。容量 500 MW のパイプラインで構成される液体水素-超電導ハイブ リッドエネルギー輸送システムは, 通常の電力 $2.7 \mathrm{GW}$, 貯蔵性のエネルギー500 MW を輸送でき, 4 時間のピーク 対応であれば約 2 倍の負荷に電力を供給できる。さらに, 輸送した液体水素は SMES などの超電導コイルを冷却で きる。特に, 負荷近傍での SMES の運転は電力品質を高 くできるので, 電力システムにとって有望である。今後 は，これらについて検討する予定である。

本研究の一部は, (独) 日本学術振興会の特別研究員 DC 研究奨励費の助成を得たものである。

\section{参 考 文 献}

1) S. Kamiya: "Development of transport and storage technologies for large-mass liquid hydrogen," TEION KOGAKU 38 (2003) 193-203

神谷祥二：「液体水素輸送・貯蔵技術の開発」, 低温工学 38 (2003) 193-203

2) S. Kamiya: "Development of a $\mathrm{LH}_{2}$ container-advantages and disadvantages of $\mathrm{LH}_{2}$, JHPI 42 (2004) 42-49

神谷祥二:「液体水素コンテナの開発一液体水素の長所と短 所一」，圧力技術 42 (2004) 42-49

3) J. Nagamatsu, N. Nakagawa, T. Muranaka, Y. Zenitani and J. Akimitsu: "Superconductivity at $39 \mathrm{~K}$ in magnesium diboride," Nature 410 (2001) 63-64

4) S. Kobayashi, T. Kaneko, T. Kato, J. Fujikami and K. Sato: “A novel scaling of magnetic field dependencies of critical currents for Ag-sheathed Bi-2223 superconducting tape,” Physica C 258 (1996) 336-340

5) M. Inoue, T. Kiss, Y. Tsuda, H. Sawa, M. Takeo, S. Awaji, K. Watanabe, Y. Iijima, K. Kakimoto, T. Saitoh, J. Matsuda, Y. Tokunaga, T. Izumi and Y. Shiohara: "High magnetic field properties of critical current density in $\mathrm{Y}_{1} \mathrm{Ba}_{2} \mathrm{Cu}_{3} \mathrm{O}_{7-\delta}$ coated conductor fabricated by improved TFA-MOD process," IEEE Tran. Appl. Supercond. 15 (2005) 2574-2577

6) T. Koizumi, T. Hasegawa, N. Ohtani, H. Kitaguchi, H. Kumakura, H. Miao and K. Togano: "Development of 100m-class Bi-2212 multilayer superconducting tapes by PAIR process," Adv. Cryog. Eng. 46 (2000) 583-590

7) T. Nakayama, T. Yagai, M. Tsuda and T. Hamajima: "Study of combined DC micro grid of liquid hydrogen and superconducting equipment," Abstracts of CSJ Conference 76 (2003) 12 中山知紀, 谷貝 剛, 津田 理, 濱島高太郎: 「液体水素と 超電導機器の複合DCマイクロ・グリッドの検討」, 第76回 2007 年度春季低温工学・超電導学会講演概要集 (2007) 12

8) T. Nakayama, T. Yagai, M. Tsuda and T. Hamajima: "Energy management on hydrogen-superconducting DC micro grid," Annual Meeting Record I.E.E 5 (2008) 233

中山知紀, 谷貝 剛, 津田 理, 濱島高太郎: 「水素一超電 導DCマイクロ・グリッドにおけるエネルギーマネジメン 卜」，平成20年電気学会全国大会講演論文集 5 (2008) 233

9) T. Hamajima, T. Nakayama, M. Tsuda and T. Yagai: "Synergy effects combined with liquid hydrogen and superconducting power machines," Abstracts of CSJ Conference 75 (2006) 57

濱島高太郎, 中山知紀, 津田 理, 谷貝 剛: 「液体水素と 超電導電力機器の相乗効果」, 第75回 2006 年度秋季低温工 学・超電導学会講演概要集 (2006) 57

10) T. Hamajima, M. Tsuda, T. Yagai, O. Ichinokura, K. Watanabe, K. Ohira, H. Kumakura, H. Hirabayashi, T. Shintomi and Y. Makida: "Study on superconducting power machines cooled by liquid hydrogen," Abstracts of CSJ Conference 72 (2005) 28

濱島高太郎, 津田 理, 谷貝 剛, 一八倉理, 渡辺和雄, 大 平勝秀, 熊倉浩明, 平林洋美, 新冨孝和, 槙田康博：「液体 水素冷却超電導電力機器の検討」, 第72回 2005 年度春季低 温工学・超電導学会講演概要集 (2005) 28

11) 石郷岡猛; 「液体水素冷却高温超電導直流電力ケーブルの可 能性」, 電気学会超電導応用電力機器 - 回転機合同研究会資 料, ASC 94-21 (1994) 1-10

12) L. Trevisani, M. Fabbri and F. Negrini: "Long distance renewableenergy-sources power transmission using hydrogen-cooled $\mathrm{MgB}_{2}$ superconducting line," Cryogenics 47 (2007) 113-120

13) 社団法人電気学会 編: 「電気学会技術報告」, 897 (2002) 37

14) A. Kimura and K. Yasuda: " $R$ \& D of superconductive cable in Japan,” IEEE Trans. Appl. Supercond. 15 (2005) 1818-1822

15) S. Mukoyama, M. Yagi, N. Hirano, N. Amemiya, N. Kashima, S. Nagaya, T. Izumi and Y. Shiohara: "Study of an YBCO HTS transmission cable system," Physica C 463-465 (2007) 1150-1153

16) 社団法人低温工学協会 編：「超伝導・低温工学ハンドブッ ク」, オーム社 (1993)

17) H. Neumann: "Concept for thermal insulation arrangement within a flexible cryostat for HTS power cables," Cryogenics 44 (2004) 93-99

18) I.A. Davydenkov, S.B. Milman, M.G. Velikanova, L.E. Kotov and A.G. Perestoronin: "Study of Dewar multishield insulation systems at 4.2-293 K," Cryogenics 33 (1993) 1137-1141

19) R. Musenich, P. Fabbricatore, S. Farinon, C. Ferdeghini, G. Grasso, M. Greco, A. Malagoli, R. Marabotto, M. Modica, D. Nardelli, A. S. Siri, M. Tassisto and A. Tumino: "Behavior of $\mathrm{MgB}_{2}$ react \& 
wind coils above 10 K," IEEE Tran. Appl. Supercond. 15 (2005) 1452-1456

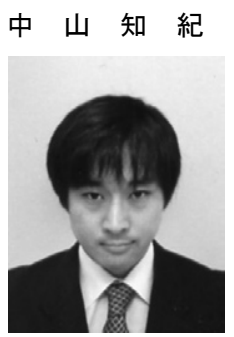

1979 年 1 月 6 日生。2005 年信州大学繊維 学部機能機械学科卒業。2007 年東北大学大学 院工学研究科博士前期課程(電気 - 通信工学専 攻)修了。現在, 東北大学大学院工学研究科 日本学術振興会特別研究員 $\mathrm{DC}$ 。超電導と水 素の複合化システムの研究に従事。低温工学 協会, 電気学会会員。工学修士。

大 友 勝 志

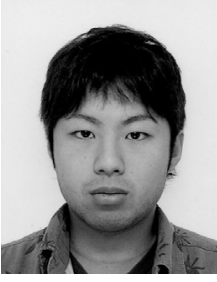

谷 貝 剛

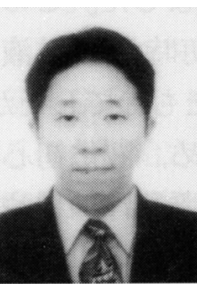

1973 年 5 月 16 日生。 2003 年東北大学大学 院工学研究科博士後期課程修了。同年, 東北 大学大学院工学研究科助手。応用電力システ ム工学講座にて超電導の電力応用研究に従 事。低温工学協会, 電気学会, プラズマ・核

融合学会会員。工学博士。 の研究に従事。低温工学協会会員。工学学 士。

1985 年 5 月 5 日生。 2008 年東北大学電 気・情報物理工学科卒業。同年, 東北大学大 学院工学研究科博士前期課程(電気・通信工学 専攻)入学。現在, 水素と高温超電導ケーブル

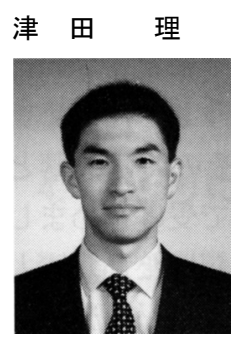

1967 年 1 月 15 日生。平成 7 年早稲田大学 大学院理工学研究科同博士後期課程修了。早 稲田大学助手, MIT 客員研究員, 早稲田大学 理工学総合研究センター客員講師, 山口大学 助手, 山口大学助教授。現在, 東北大学准教 授。超電導応用に関する研究に従事。低温工 学協会, 電気学会会員。工学博士。

1948 年 2 月 7 日生。1 977 年東京工業大学 $\frac{2}{2 y}$ 大学院理工学研究科博士課程修了。同年, (株)東芝に入社。核融合装置, 超電導応用機 器の技術開発に従事。1999 年山口大学工学部 教授。2003 年東北大学大学院工学研究科教 授。現在に至る。超電導応用の研究に従事。 低温工学協会, 電気学会, IEEE, プラズマ・ 核融合学会, 日本物理学会会員。工学博士。 